\title{
PENINGKATAN PROSES DAN HASIL BELAJAR MATEMATIKA MENGGUNAKAN MODEL PROBLEM BASED LEARNING (PBL) BERBANTU MEDIA KARTU SOAL PADA SISWA KELAS 5 SD NEGERI SIDOREJO LOR 03 SALATIGA SEMESTER GENAP TAHUN AJARAN $2017 / 2018$
}

\author{
Damasus Fajar Nugroho', Nyoto Harjono 2 , Gamaliel Septian Airlanda ${ }^{3}$ \\ ${ }^{1}$ Pendidikan Guru Sekolah Dasar, Universitas Kristen Satya Wacana, fajar2nugraha@gmail.com \\ ${ }^{2}$ Pendidikan Guru Sekolah Dasar, Universitas Kristen Satya Wacana, har.john59@gmail.com \\ ${ }^{3}$ Pendidikan Guru Sekolah Dasar, Universitas Kristen Satya Wacana, gama.airlanda@staff.uksw.edu
}

\section{INFO ARTIKEL}

Riwayat Artikel:

Diterima: 23-03-2018

Disetujui: 05-04-2018

\section{Kata Kunci:} Kartu Soal, Proses Pembelajaran, Hasil Belajar, Volume Kubus dan Balok
Problem Based Learning,

\section{ABSTRAK}

Abstrak: Penelitian ini merupakan penelitian tindakan kelas (PTK). Hasil penelitian adalah bahwa penerapan model $P B L$ berbantu media kartu soal dapat memperbaiki proses dan hasil belajar matematika. Pada siklus I, persentase ketercapaian aktivitas guru sebesar $81 \%$ yang kemudian meningkat pada siklus II menjadi 92\% dan ketercapaian aktivitas siswa pada siklus I sebesar $82,67 \%$ yang kemudian meningkat pada siklus II menjadi 93,33\%. Peningkatan hasil belajar matematika dilihat dari aspek kognitif persentase ketuntasan untuk siklus I mencapai $64,29 \%$ dan meningkat pada siklus II menjadi $83,33 \%$.

\begin{abstract}
This research is a classroom action research (PTK). The result of this research is that the application of PBL model assisted by media of problem card can improve the process and result of learning mathematics. In cycle I, the percentage of achievement of teacher activity was $81 \%$ which then increased in cycle /I to $92 \%$ and the achievement of student activity in cycle I was $82.67 \%$ which then increased in cycle II to $93,33 \%$. Improvement of learning mathematic content is seen from the cognitive aspect of the percentage of completeness for cycle / reaches $64.29 \%$ and increases in cycle I/ to $83.33 \%$.
\end{abstract}

\section{A. LATAR BELAKANG}

Peraturan menteri pendidikan nasional nomor 22 tahun 2006, pelaksanaan pendidikan nasional yang berdasarkan Pancasila dan Undang-Undang Dasar Negara Republik Indonesia Tahun 1945 berfungsi untuk mengembangkan kemampuan dan membentuk watak serta peradaban bangsa yang bermartabat dalam rangka mencerdaskan kehidupan bangsa, bertujuan untuk mengembangkan potensi peserta didik agar menjadi manusia yang beriman dan bertakwa kepada Tuhan Yang Maha Esa, berakhlak mulia, sehat, berilmu, cakap, kreatif, mandiri, dan menjadi warga negara yang demokratis serta bertanggung jawab. Untuk mengemban fungsi tersebut pemerintah menyelenggarakan suatu sistem pendidikan nasional sebagaimana tercantum dalam Undang-Undang Nomor 20 Tahun 2003 tentang Sistem Pendidikan Nasional.

Dalam rangka pembaharuan sistem pendidikan nasional telah ditetapkan visi, misi dan strategi pembangunan pendidikan nasional. Visi pendidikan nasional adalah terwujudnya sistem pendidikan sebagai pranata sosial yang kuat dan berwibawa untuk memberdayakan semua warga negara Indonesia berkembang menjadi manusia yang berkualitas sehingga mampu dan proaktif menjawab tantangan zaman yang selalu berubah. Terkait dengan visi tersebut telah ditetapkan serangkaian prinsip penyelenggaraan pendidikan untuk dijadikan landasan dalam pelaksanaan reformasi pendidikan. Salah satu prinsip tersebut adalah pendidikan diselenggarakan sebagai proses pembudayaan dan pemberdayaan peserta didik yang berlangsung sepanjang hayat. Dalam proses tersebut diperlukan guru yang memberikan keteladanan, membangun kemauan, dan mengembangkan potensi dan kreativitas peserta didik. Implikasi dari prinsip ini adalah pergeseran paradigma proses pendidikan, yaitu dari paradigma pengajaran ke paradigma pembelajaran. Pembelajaran adalah proses interaksi peserta didik dengan guru dan sumber belajar pada suatu lingkungan belajar. Proses pembelajaran perlu direncanakan, dilaksanakan, dinilai, dan diawasi agar terlaksana secara efektif dan efisien (Peraturan Menteri Pendidikan Nasional Nomor 41 Tahun 2007).

Matematika adalah pembelajaran yang sangat penting diajarkan di sekolah dasar. Hal ini karena matematika mendasari ilmu-ilmu lain, membekali siswa berpikir kritis, serta dibutuhkan dalam kehidupan 
sehari-hari siswa untuk membantu memecahkan persoalan sehari-hari. Sekolah Dasar (SD) merupakan lembaga pendidikan dimana siswa umurnya berkisar antara 7 tahun sampai dengan 13 tahun. Menurut Piaget (dalam Heruman 2012: 1-2), mereka berada pada fase operasional konkrit. Kemampuan yang tampak pada fase ini adalah kemampuan dalam proses berpikir untuk mengoperasikan kaidah-kaidah logika, meskipun masih terikat dengan objek yang bersifat konkrit.

Menurut Johnson dan Rising (dalam Karso dkk, 2011: 139) matematika adalah pola pikir pola mengorganisaikan pembuktian yang logik; matematika adalah bahasa, bahasa yang menggunakan istilah yang didefinisikan dengan cermat, jelas dan akurat representasinya dengan simbol dan padat, lebih berupa bahasa simbol mengenai arti daripada bunyi; matematika adalah pengetahuan struktur yang terorganisasi, sifat-sifat atau teori-teori dibuat secara deduktif berdasarkan kepada unsur yang tidak didefinisikan, aksioma, sifat atau teori yang telah dibuktikan kebenarannya; matematika adalah ilmu tentang pola keteraturan pola atau ide; dan matematika itu adalah suatu seni, keindahannya terdapat pada keterurutan dan keharmonisannya. Lebih lanjut menurut Wahyudi (2011: 1) matematika adalah ilmu dasar yang menjadi alat untuk mempelajari ilmu-ilmu yang lain. Oleh karena itu penguasaan terhadap matematika diperlukan dan konsep-konsep yang harus dipahami dengan benar sejak dini. Konsep-konsep dalam matematika merupakan suatu rangkaian sebab akibat. Suatu konsep disusun berdasarkan konsepkonsep sebelumnya dan akan menjadi dasar konsep selanjutnya. Sehingga dapat disimpulkan bahwa matematika adalah pola pikir pengetahuan yang cermat, jelas, akurat berdasarkan pola, ide, teori yang telah dibuktikan kebenarannya yang mengandung ilmu pengetahuan tentang ruang, bilangan, hubungan antara bilangan dan prosedur operasional yang digunakan dalam menyelesaikan masalah mengenai bilangan.

Menurut Dimyati dalam Sriyanto (2011: 26) pembelajaran matematika di SD merupakan kegiatan guru secara terprogram dalam desain instruksional, untuk membuat siswa belajar secara aktif, yang menekankan pada penyediaan sumber belajar alat bantu berupa media, dan alat peraga yang dapat memperjelas apa yang akan disampaikan oleh guru sehingga lebih cepat dipahami dan dimengerti oleh siswa. Pembelajaran berarti aktivitas guru dalam merancang bahan pengajaran agar proses pembelajaran dapat berlangsung secara efektif, yakni siswa dapat belajar secara aktif dan bermakna. Dalam mengajarkan matematika, guru harus memahami bahwa kemampuan setiap siswa berbeda-beda, serta tidak semua siswa menyenangi mata pelajaran matematika. Adapun menurut Wragg (Ahmad Susanto 2013: 188) pembelajaran matematika di SD merupakan pembelajaran yang memudahkan siswa untuk mempelajari sesuatu yang bermanfaat, seperti fakta, keterampilan, nilai, konsep, dan bagaimana hidup serasi dengan sesama, atau suatu hasil belajar yang diinginkan. Dengan demikian, diketahui bahwa proses pembelajaran matematika bukan sekedar transfer ilmu dari guru ke siswa, melainkan suatu proses kegiatan, yaitu terjadi hubungan antara guru dan siswa, antara siswa dan siswa, serta antara siswa dan lingkungan sekitarnya. Selain itu matematika bukan hanya sebagai transfer of knowledge, yang mengandung makna bahwa siswa merupakan objek dari belajar, namun hendaknya siswa menjadi subjek dalam belajar. Sehingga dapat dikatakan seseorang yang belajar matematika apabila pada diri seseorang terjadi suatu kegiatan yang dapat mengakibatkan perubahan tingkah laku yang berkaitan dengan matematika. Perubahan tersebut terjadi dari tidak tahu sesuatu menjadi tahu konsep matematika, dan mampu menggunakannya dalam materi lanjut dalam kehidupan sehari-hari.

Berdasarkan pendapat diatas pembelajaran matematika di SD adalah pembelajaran yang memudahkan siswa mempelajari sesuatu yang bermanfaat, hasil belajar yang diinginkan untuk mengembangkan kreativitas berpikir serta dapat ditingkatkan kemampuan berpikir dan pengetahuan siswa.

Sriyanto (2011: 17) menyatakan secara umum tujuan diberikannya matematika di SD adalah untuk membantu siswa mempersiapkan diri agar sanggup menghadapi perubahan keadaan di dalam kehidupan dan di dunia yang selalu berkembang, melalui latihan bertindak atas dasar pemikiran secara logis, rasional, dan kritis, serta mempersiapkan siswa agar dapat menggunakan matematika dan pola pikir dalam mempelajari berbagai ilmu pengetahuan dikehidupan sehari-harinya. Tujuan pendidikan disekolah lebih ditekankan pada penataan nalar, dasar, dan pembentukan sikap, serta ketrampilan dalam penerapan matematika.

Hasil belajar menurut Sudjana (2010) merupakan kemampuan-kemampuan yang diterima siswa setelah menerima pengalaman belajar. Lebih lanjut Dimyati dan Mudjiono (2013: 3) menyebutkan bahwa hasil belajar merupakan hasil dari suatu interaksi tindak belajar dan tindak mengajar. Dari sisi guru, tindak mengajar diakhiri dengan proses evaluasi hasil belajar. Dari sisi siswa, hasil belajar merupakan berakhirnya penggal dan puncak proses belajar. Adapun hasil belajar menurut Nawawi dalam Susanto (2013: 5) adalah tingkat keberhasilan siswa dalam mempelajari materi pelajaran di sekolah yang dinyatakan dalam skor yang diperoleh dari hasil tes dalam materi pelajaran tertentu. Berdasarkan pendapat-pendapat tersebut dapat disimpulkan bahwa hasil belajar adalah hasil akhir dari proses kegiatan belajar siswa yang sesuai dengan tujuan pendidikan untuk mengetahui sejauh mana materi pelajaran sudah diterima oleh siswa setelah mengikuti 
materi pelajaran tertentu yang dapat diukur dengan tes dan hasilnya dinyatakan dalam bentuk nilai.

Teori Taksonomi Bloom (Sudjana, 2010) mengklasifikasikan hasil belajar ke dalam 3 ranah yaitu (1) ranah kognitif berkenaan dengan hasil belajar intelektual yang terdiri dari enam aspek diantaranya penguatan, pemahaman, penerapan, analisis, sintesis, evaluasi; (2) ranah afektif berkaitan dengan sikap yang terdiri dari lima aspek diantaranya penerimaan, respon, penilaian, organisasi, karakterisasi; (3) ranah psikomotorik berkaitan dengan keterampilan dan kemampuan bertindak yang terdiri dari enam aspek diantaranya gerakan refleks, keterampilan pada gerakan-gerakan dasar, kemampuan perseptual, kemampuan di bidang fisik, gerakan-gerakan skill, kemampuan yang berkenaan dengan komunikasi. Oleh karena itu hasil belajar dalam penelitian ini hanya dibatasi dalam ranah kognitif.

Menurut Ahmad Susanto (2013: 191) faktor rendahnya prestasi belajar matematika siswa adalah masalah klasik tentang penerapan metode pembelajaran matematika. Model pembelajaran sangat penting untuk siswa. Mendidik siswa menjadi orang yang bersifat prosedural, simbolis tertentu, yakni bekerja tetapi bukan untuk berpikir, kurang mengedepankan aspek berpikir atau analisis yang mandiri. Ada beberapa siswa yang mengaku kurang memahami soal matematika yang dikerjakan. Bahkan tidak jarang ditemui siswa yang tidak dapat menggunakan ketrampilan menyelesaikan soal apabila diberikan soal sedikit berbeda dari apa yang dipelajari atau dicontohkan. Hal ini menunjukkan bahwa siswa mengalami kesulitan dalam menyelesaikan mata pelajaran matematika.

Berdasarkan hasil observasi di SD Negeri Sidorejo Lor 03 Salatiga kelas 5, diketahui bahwa nilai matematika masih rendah, hal ini terlihat dari 42 siswa yang mengikuti ulangan harian, terdapat 20 siswa (48\%) yang memiliki nilai di bawah siswa belum aktif dalam bertanya dan menjawab, siswa berbicara sendiri saat guru menerangkan, kurangnya media pembelajaran, dan siswa kurang bersemangat dalam mengikuti pembelajaran matematika. Selain itu, saat guru memberikan tugas latihan dan meninggalkan kelas, siswa cenderung tidak mengerjakan dan ribut sendiri didalam kelas.

Dari data yang diperoleh dapat disimpulkan bahwa proses pembelajaran matematika belum sesuai yang diharapkan, hal ini terlihat masih banyak siswa yang mendapatkan nilai di bawah KKM. Dilihat dari latar belakang, peneliti tertarik untuk melakukan perbaikan melalui Penelitian Tindakan Kelas (PTK) dengan judul "Peningkatan Proses dan Hasil Belajar Matematika Menggunakan Model Problem Based Learning (PBL) Berbantu Media Kartu Soal pada Siswa Kelas 5 SD Negeri Sidorejo Lor 03 Salatiga Semester Genap Tahunn Ajaran 2017/2018”. Dengan menggunakan model pembelajaran Problem Based Learning (PBL) berbantu media kartu soal diharapkan dapat meningkatkan proses dan hasil belajar.

Model pembelajaran PBL digunakan untuk mendukung pola berpikir siswa pada tingkatan yang lebih tinggi pada situasi yang berorientasi masalah, termasuk belajar "how to learn". Pada model pembelajaran ini guru berperan untuk mengajukan masalah, memberikan pertanyaan dan memfasilitasi untuk penyelidikan dan dialog. Dalam model pembelajaran PBL guru harus memberikan ruang yang ditata sedemikian rupa sehingga nyaman dan terbuka untuk saling bertukar pikiran sehingga siswa memiliki kesempatan untuk menambah kemampuan menemukan dan kecerdasan (Wisudawati dan Sulistyowati 2014: 88). Menurut Agus (2013: 283) menyebutkan bahwa PBL merupakan suatu model pembelajaran yang didasarkan pada prinsip menggunakan masalah sebagai titik awal akuisi dan interasi pengetahuan baru. Lebih lanjut menurut Hosnan (2014: 295) mengatakan bahwa PBL merupakan suatu model pembelajaran yang menggunakan pendekatan pembelajaran pada suatu masalah autentik, sehingga dengan hal itu siswa dapat merangkai pengetahuannya sendiri, menggembangkan ketrampilan yang lebih tinggi, membuat siswa lebih mandiri dan membuat siswa percaya diri. Adapun pembelajaran PBL menurut Ngalimun (2014: 89) adalah salah satu model pembelajaran inovatif yang dapat memberikan kondisi belajar aktif kepada siswa.

Dari definisi-definisi tersebut dapat disimpulkan bahwa model pembelajaran PBL merupakan suatu proses pembelajaran kerja kelompok dimana siswa diberikan masalah dalam situasi yang berorientasi pada masalah dalam kehidupan sehari-hari sehingga mendorong siswa dalam berfikir kritis, memandirikan siswa, meningkatkan kepercayaan diri, dan ketrampilan pemecahan masalah dalam rangka memperoleh pengetahuan baru.

Model pembelajaran PBL dirancang untuk membantu guru memberikan informasi yang sebanyakbanyaknya kepada siswa. Menurut Resnick dalam Trianto (2013: 94-96) model pembelajaran PBL memiliki tujuan (1) membantu siswa mengembangkan keterampilan berfikir dan keterampilan pemecahan masalah, (2) belajar peranan orang dewasa yang autentik.

Menurut Rusmono (2012: 81) langkah-langkah model pembelajaran PBL yaitu (1) mengorganisasikan siswa kepada masalah, (2) mengorganisasikan siswa untuk belajar, (3) membantu penyelidikan mandiri dan kelompok, (4) mengembangkan dan mempresentasikan hasil karya, (5) menganalisis dan mengevaluasi proses pemecahan masalah. Lebih lanjut menurut Hosnan (2014: 301) langkah-langkah model pembelajaran PBL yaitu (1) orientasi siswa pada suatu masalah, (2) mengorganisasikan siswa untuk belajar, (3) membimbing penyelidikan indivudual dan kelompok, (4) mengembangkan dan menyajikan hasil karya yang telah 
didiskusikan dalam kelompok belajar, (5) menganalisis dan mengevaluasi hasil karya. Adapun menurut Daryanto (2014: 29) langkah-langkah model pembelajaran PBL yaitu (1) orientasi peserta didik kepada masalah, (2) mengorganisasikan peserta didik, (3) membimbing penyelidikan individu dan kelompok, (4) mengembangkan dan menyajikan hasil karya, (5) menganalisa dan mengevaluasi proses pemecahan masalah.

Menurut Arends dalam Warsono (2013: 151), kelebihan model pembelajaran PBL adalah (1) siswa akan terbiasa menghadapi masalah dan merasa tertantang untuk menyelesaikan masalah tidak hanya terkait dengan pembelajaran dalam kelas tetapi juga menghadapi masalah yang ada dalam kehidupan seharihari, (2) memupuk solidaritas sosial dengan terbiasa berdiskusi dengan teman sekelompok kemudian berdiskusi dengan teman sekelasnya, (3) makin mengakrabkan guru dengan siswa, (4) karena ada kemungkinan suatu masalah harus diselesaikan siswa melalui eksperimen hal ini juga akan membiasakan siswa dalam menerapkan model pembelajaran. Lebih lanjut menurut Rizema Putra Sitiava (2013: 82-83), kelebihan model pembelajaran PBL adalah (1) siswa lebih memahami konsep yang diajarkan melibatkan siswa secara aktif dalam memecahkan masalah dan menuntut keterampilan berpikir siswa yang lebih tinggi, (2) pengetahuan tertanam berdasarkan skemata yang dimiliki oleh siswa, sehingga pembelajaran lebih bermakna, (3) siswa dapat merasakan manfaat pembelajaran, karena masalah-masalah yang diselesaikan langsung dikaitkan dengan kehidupan nyata, (4) menjadikan siswa lebih mandiri dan dewasa, mampu memberi aspirasi dan menerima pendapat orang lain, pengkondisian siswa dalam belajar kelompok yang saling berinteraksi terhadap pembelajaran dan temannya sehingga pencapaian ketuntasan belajar siswa dapat diharapkan, (5) menumbuhkan kemapuan kreativitas siswa, baik secara individual maupun kelompok, karena hampir di setiap langkah menuntut adanya keaktifan siswa.

Menurut Arends dalam Warsono (2013: 151), kelemahan model pembelajaran PBL adalah (1) tidak banyak guru yang mampu mengantarkan siswa kepada pemecahan masalah, (2) seringkali memerlukan biaya mahal dan waktu yang panjang, (3) aktivitas siswa yang dilaksanakan di luar sekolah sulit di pantau oleh guru. Lebih lanjut menurut Rizema Putra Sitiava (2013: 84), kelemahan model pembelajaran PBL adalah (1) bagi siswa yang malas, tujuan dari model tersebut tidak dapat dicapai, (2) membutuhkan banyak waktu dan dana, (3) tidak semua mata pelajaran bisa diterapkan dengan PBL.

Menurut Berliana (2012: 1) media kartu soal adalah sarana agar siswa dapat belajar secara aktif terlibat dalam kegiatan belajar, berfikir aktif dan kritis didalam belajar dan secara inovatif dapat menemukan cara atau pembuktian teori matematika. Pembelajaran matematika dengan menggunakan media kartu soal menerapkan proses belajar kelompok dalam bentuk kegiatan mencatat konsep materi matematika untuk meningkatkan pemahaman siswa.

Menurut Sudarmono (2008: 9) terdapat langkahlangkah media kartu soal (1) setiap siswa diberikan kartu soal berupa kertas manila berukuran $10 \mathrm{~cm} \times 15 \mathrm{~cm}$ untuk menuliskan soal cerita sesuai materi yang dibahas, (2) kartu yang telah berisi soal yang telah dikumpulkan siswa dikumpul kembali pada guru, (3) siswa dibagi menjadi beberapa kelompok, setiap kelompok terdiri atas 3 sampai 4 orang siswa, (4) salah seorang siswa diminta untuk mengocok kartu soal yang telah berisi pertanyaan kemudian membagikannya secara acak kepada teman-temannya dan masing-masing mendapat satu buah kartu, (5) setiap kelompok memecahkan soal yang telah diterima secara bersama-sama, (6) koreksi jawaban atas tugas kelompok, (7) pembahasan terutama soal-soal yang tidak dapat dikerjakan dengan benar, (8) siswa bertanya tentang hal-hal yang belum dipahami, (9) guru bersama-sama siswa membuat kesimpulan tentang hal yang baru dipelajari, (10) tes untuk mengetahui kemampuan peserta didik dalam menyelesaikan soal cerita.

Beberapa penelitian tentang peningkatan model pembelajaran PBL terhadap hasil belajar diantaranya penelitian Rifki Khamdani (2012) yang berjudul "Penggunaan Model Pembelajaran Berbasis Masalah (PBL) Untuk Meningkatkan Hasil Belajar Matematika Siswa Kelas 5 SD Negeri Kemligi Kecamatan Wonotunggal Kabupaten Batang Tahun Pelajaran 2013/2014", penelitian Rizka Vitasari (2012) yang berjudul "Peningkatan Keaktifan dan Hasil Belajar Matematika Melalui Model Problem Based Learning Siswa Kelas 5 SD Negeri 5 Kutasari", dan penelitian Siti Novi Andriastutik (2013) yang berjudul "Penerapan Model Problem Based Learning (PBL) Pada Pembelajaran Matematika dalam Upaya Meningkatkan Hasil Belajar Matematika Siswa Kelas 5 Semester II Sekolah Dasar Negeri 6 Sindurejo Tahun ajaran 2012/2013".

Selain penelitian yang meneliti pengaruh PBL terhadap hasil belajar terdapat pula penelitian yang mengkolaborasikan PBL dengan media pembelajaran, diantaranya penelitian Ni Made Putri Andriaswari (2016) yang mengkolaborasikam PBL dengan media konkret pada siswa SD kelas 5, penelitian Wafik Khoiri (2013) yang mengkolaborasikan PBL dengan multimedia dalam pembelajaran matematika pada siswa SMP kelas 5II, dan penelitian Ari Haryanto (2011) yang mengkolaborasikan PBL berbantu permainan ular tangga. Maka penelitian ini akan mengkolaborasikan PBL dengan media kartu soal.

\section{B. METODE PENELITIAN}

Jenis penelitian ini menggunakan kuantitatif dengan deskripsi statistik. Penelitian dilakukan di SD Negeri 
Sidorejo Lor o3 Salatiga yang terletak di tepi jalan dan dikelilingi pemukiman warga, sehingga dapat dijangkau dengan mudah baik dengan kendaraan pribadi maupun kendaraan umum. Penelitian ini dilakukan pada semester II tahun ajaran 2017/2018.

Penelitian tindakan kelas siklus I dilaksanakan sebanyak 3 kali pertemuan yaitu 2 kali pertemuan tatap muka dan 1 kali pertemuan evaluasi. Penelitian ini dilaksanakan pada bulan November 2017 sampai dengan Januari 2018 pada semester genap tahun ajaran 2017/2018. Subjek penelitian ini adalah siswa kelas 5 SD Negeri Sidorejo Lor 03 Salatiga. Siswa kelas 5 SD Negeri Sidorejo Lor 03 Salatiga berjumlah 42 siswa terdiri dari 16 siswa laki-laki dan 26 siswa perempuan dengan karateristik siswa yang bervariasi.

Pada siklus I terdiri dari tiga tahap meliputi, tahap perencanaan tindakan, pelaksanan tindakan dan observasi, serta refleksi. Hasil refleksi pada siklus I digunakan untuk perbaikan pada pembelajaran siklus II. Tahapan pada siklus II meliputi, tahap perencanaan tindakan, tahap pelaksanaan tindakan dan observasi, serta refleksi. Apabila pembelajaran siklus II sudah memenuhi pencapaian untuk proses belajar meningkat secara signifikan minimal $15 \%$ dan ketuntasan hasil belajar secara klasikal dengan nilai rata-rata hasil belajar matematika meningkat sebesar $80 \%$ dari nilai KKM ( $\geq$ 75) yang telah ditentukan. Maka tidak perlu diadakan perbaikan kembali dan penerapan model pembelajaran PBL berbantu media kartu soal pada pembelajaran matematika dinyatakan berhasil.

Pada penelitian ini, peneliti menggunakan tes tertulis sebagai alat pengumpulan data hasil belajar siswa kelas 5 pelajaran matematika dan dalam mengamati proses pembelajaran peneliti menggunakan lembar observasi. Pada uji validitas, instrumen soal tes siklus I dan siklus II instrumen soal valid jika koefisien corrected item to total correlation $r \geq 0,312$. Pada siklus I uji reliablilitas istrumen soal setelah dikurangi item yang tidak valid diuji tingkat reliabilitasnya dengan Cronbach's Alpha sebesar 0,822 dan pada siklus II instrumen soal setelah dikurangi item yang tidak valid diuji tingkat reliabilitasnya dengan Cronbach's Alpha sebesar o,839.

Data yang diperoleh dari hasil pelaksanaan penelitian tindakan kelas adalah data kuantitatif. Penelitian ini menggunakan analisis kuantitatif dengan statistik deskriptif. Sedangkan data hasil belajar matematika dianalisis menggunakan teknik analisis deskriptif komparatif untuk membandingkan hasil belajar setelah tindakan siklus I dan siklus II.

\section{HASIL DAN PEMBAHASAN}

\section{Deskripsi Pra Siklus}

Berdasarkan pengamatan terhadap proses belajar mengajar matematika siswa kelas 5 SD Negeri Sidorejo Lor 03 Salatiga sebelum dilaksanakan tindakan menunjukan adanya permasalahan. Proses pembelajaran matematika masih berpusat pada guru, akibatnya siswa menjadi pasif dan kurang antusias mengikuti pembelajaran. Terbukti dari hasil observasi aktivitas guru prasiklus dari 20 indikator pengamatan memperoleh skor 71 dengan persentasae $71 \%$ masuk dalam kategori cukup. Kemudian aktivitas siswa prasiklus dari 15 indikator memperoleh skor 51 dengan persentase $68 \%$ masuk dalam kategori kurang. Hasil belajar yang belum optimal berdampak pada rendahnya hasil belajar. Hasil tes ulangan harian matematika menunjukan nilai rata-rata 73,17 yang berarti belum mencapai KKM ( $\geq 75$ ). Nilai tertinggi yang diperoleh siswa adalah 88 sedangkan nilai terendah 56 . Kemudian ketuntasan belajar prasiklus sebanyak 22 siswa dinyatakan tuntas atau 52\% dari keseluruhan siswa, sedangkan yang dinyatakan belum tuntas sebanyak 20 siswa atau $48 \%$ dari keseluruhan siswa.

\section{Deskripsi Siklus I}

Pelaksanaan tindakan siklus I ini terdiri dari tiga pertemuan, yaitu pertemuan 1, 2 dan 3 yang berlangsung pada hari Kamis, Jumat, Sabtu tanggal 11, 12, 13 Januari 2018. Pada tahap perencanaan tindakan penulis menyusun RPP pembelajaran matematika dengan model pembelajaran $P B L$ berbantu media kartu soal pokok bahasan volume kubus dan balok, menyiapkan alat dan media pembelajaran, daftar presensi siswa, instrumen tes evaluasi, lembar kerja siswa. Tahap pelaksanaan tindakan penulis dan guru kolabolator melaksanakan tindakan pembelajaran matematika pokok bahasan volume kubus dan balok menggunakan model pembelajaran $P B L$ berbantu media kartu soal yang telah disusun pada tahap sebelumnya. Pada tahap observasi dilakukan oleh observer untuk mengamati aktivitas belajar meliputi aktivitas guru dan aktivitas siswa selama kegiatan pembelajaran matematika menggunakan model pembelajaran $P B L$ berbantu media kartu soal. Kemudian setelah tindakan pembelajaran terlaksana secara keseluruhan dilakukan refleksi sebagai bahan perbaikan dengan membandingkan hasil tindakan selama proses pembelajaran dengan indikator yang diharapkan.

Berdasarkan pengamatan terhadap proses pembelajaran matematika menggunakan model $P B L$ berbantu media kartu soal pada siswa kelas 5 SD Negeri Sidorejo Lor 03 Salatiga diperoleh data aktivitas belajar siklus I. Aktivitas belajar meliputi aktivitas guru dan sktivitas siswa. Aktivitas guru adalah pelaksanaan sintaks model pembelajaran $P B L$ berbantu media kartu soal oleh guru dalam pembelajaran matematika yang terdiri dari 20 indikator, pengamatan dengan rentang skor penilaian 1-5 disajikan pada tabel 1 sebagai berikut.

TABEL 1

HASIL OBSERVASI AKTIVITAS GURU SIKLUS I

\begin{tabular}{|c|l|c|c|c|}
\hline \multirow{2}{*}{ No } & \multirow{2}{*}{$\begin{array}{c}\text { Aspek } \\
\text { yang } \\
\end{array}$} & Indikator & \multicolumn{2}{|c|}{ Skor } \\
\cline { 4 - 5 } & Diamati & & Pertemuan & Pertemuan \\
$\mathbf{1}$ & $\begin{array}{l}\text { Kegiatan } \\
\text { Awal }\end{array}$ & $1-5$ & 23 & 23 \\
\hline
\end{tabular}




\begin{tabular}{|c|l|c|c|c|}
\hline 2 & $\begin{array}{l}\text { Kegiatan } \\
\text { Inti }\end{array}$ & $6-17$ & 40 & 45 \\
\hline 3 & $\begin{array}{l}\text { Kegiatan } \\
\text { Akhir }\end{array}$ & $18-20$ & 13 & 13 \\
\hline \multicolumn{3}{|c|}{ Total Skor } & 76 & 81 \\
\hline \multicolumn{2}{|c|}{ Kriteria } & Cukup & Baik \\
\hline \multicolumn{2}{|c|}{ Rata-Rata Skor Siklus 1 } \\
\hline
\end{tabular}

Sumber: hasil pengolahan data penelitian (2018)

Berdasarkan data tabel 1 dapat dilihat aktivitas guru pada pertemuan pertama dan kedua siklus I mengalami peningkatan. Pada pertemuan pertama memperoleh skor 76 dengan kriteria cukup meningkat menjadi 81 dengan kriteria baik pada pertemuan kedua. Sehingga diperoleh rata-rata skor aktivitas guru siklus I sebesar 78,5 .

Kemudian aktivitas siswa yang meliputi aktivitas siswa, yaitu kegiatan-kegiatan atau aktivitas-aktivitas yang dilakukan siswa selama pembelajaran. Observasi dilakukan menggunakan aspek pengamatan aktivitas yang terdiri dari 15 indikator, pengamatan dengan rentang skor penilaian1-5. Berdasarkan hasil observasi terhadap aktivitas siswa siklus I, diperoleh data hasil observasi yang disajikan dalam tabel 2 sebagai berikut.

TABEL 2

HASIL OBSERVASI AKTIVITAS SISWA SIKLUS I

\begin{tabular}{|c|c|c|c|c|}
\hline \multirow[b]{2}{*}{ No } & \multirow{2}{*}{$\begin{array}{c}\text { Aspek } \\
\text { yang } \\
\text { Diamati }\end{array}$} & \multirow[b]{2}{*}{ Indikator } & \multicolumn{2}{|c|}{ Skor } \\
\hline & & & $\begin{array}{c}\text { Pertemuan } \\
1\end{array}$ & $\begin{array}{c}\text { Pertemuan } \\
2\end{array}$ \\
\hline 1 & $\begin{array}{l}\text { Kegiatan } \\
\text { Awal }\end{array}$ & $1-4$ & 17 & 17 \\
\hline 2 & $\begin{array}{l}\text { Kegiatan } \\
\text { Inti }\end{array}$ & $5-13$ & 33 & 37 \\
\hline 3 & $\begin{array}{l}\text { Kegiatan } \\
\text { Akhir }\end{array}$ & $14-15$ & 8 & 8 \\
\hline \multicolumn{3}{|c|}{ Total Skor } & 58 & 62 \\
\hline \multicolumn{3}{|c|}{ Kriteria } & Cukup & Baik \\
\hline \multicolumn{3}{|c|}{ Rata-Rata Skor Siklus 1} & \multicolumn{2}{|c|}{60} \\
\hline
\end{tabular}

Sumber: hasil pengolahan data penelitian (2018)

Berdasarkan data tabel 2, Pada pertemuan pertama diperoleh total skor sebesar 58 dengan kriteria cukup dan pada pertemuan kedua sebesar 62 dengan kriteria baik. Sehingga rata-rata skor siklus 1 sebesar 60.

Selanjutnya data hasil belajar matematika siklus I pada siswa kelas 5 SD Negeri Sidorejo Lor 03 Salatiga setelah dilaksanakannya tes evaluasi di akhir siklus I. Nilai rata-rata kelas 73,71 dengan nilai tertinggi 100, sedangkan nilai terendah 50. Ketuntasan belajar siklus I diperoleh data tuntas sebanyak 27 siswa atau 64,29\% dari keseluruhan siswa, sedangkan yang belum tuntas sebanyak 15 siswa atau 35,71\% dari keseluruhan siswa. Artinya hasil belajar matematika siklus I belum memenuhi indikator hasil pencapaian $80 \%$ maka perlu dilakukan tindak lanjut pada siklus II.

\section{Deskripsi Siklus II}

Pelaksanaan tindakan siklus II ini terdiri dari tiga pertemuan, yaitu pertemuan 1, 2 dan 3 yang berlangsung pada hari Kamis, Jumat, Sabtu tanggal 18, 19, 20 Januari 2018. Pada tahap perencanaan tindakan penulis menyusun RPP pembelajaran matematika dengan model pembelajaran $P B L$ berbantu media kartu soal pokok bahasan menyelesaikan masalah yang berkaitan dengan volume kubus dan balok, menyiapkan alat dan media pembelajaran, daftar presensi siswa, instrumen tes evaluasi, lembar kerja siswa. Tahap pelaksanaan tindakan penulis dan guru kolabolator melaksanakan tindakan pembelajaran matematika pokok bahasan menyelesaikan masalah yang berkaitan dengan volume kubus dan balok menggunakan model pembelajaran $P B L$ berbantu media kartu soal yang telah disusun pada tahap sebelumnya. Pada tahap observasi dilakukan oleh observer untuk mengamati aktivitas belajar meliputi aktivitas guru dan aktivitas siswa selama kegiatan pembelajaran matematika menggunakan model pembelajaran $P B L$ berbantu media kartu soal. Kemudian setelah tindakan pembelajaran terlaksana secara keseluruhan dilakukan refleksi sebagai bahan perbaikan dengan membandingkan hasil tindakan selama proses pembelajaran dengan indikator yang diharapkan.

Berdasarkan pengamatan terhadap proses pembelajaran matematika menggunakan model $P B L$ berbantu media kartu soal pada siswa kelas 5 SD Negeri Sidorejo Lor o3 Salatiga diperoleh data aktivitas belajar siklus II. Aktivitas belajar meliputi aktivitas guru dan sktivitas siswa. Aktivitas guru adalah pelaksanaan sintaks model pembelajaran $P B L$ berbantu media kartu soal oleh guru dalam pembelajaran matematika yang terdiri dari 20 indikator, pengamatan dengan rentang skor penilaian 1-5 disajikan pada tabel 3 sebagai berikut.

TABEL 3

HASIL OBSERVASI AKTIVITAS GURU SIKLUS II

\begin{tabular}{|c|c|c|c|c|}
\hline \multirow[b]{2}{*}{ No } & \multirow{2}{*}{$\begin{array}{c}\text { Aspek } \\
\text { yang } \\
\text { Diamati }\end{array}$} & \multirow[b]{2}{*}{ Indikator } & \multicolumn{2}{|c|}{ Skor } \\
\hline & & & $\begin{array}{c}\text { Pertemuan } \\
1\end{array}$ & $\begin{array}{c}\text { Pertemuan } \\
2\end{array}$ \\
\hline 1 & $\begin{array}{l}\text { Kegiatan } \\
\text { Awal }\end{array}$ & $1-5$ & 23 & 23 \\
\hline 2 & $\begin{array}{l}\text { Kegiatan } \\
\text { Inti }\end{array}$ & $6-17$ & 52 & 56 \\
\hline 3 & $\begin{array}{l}\text { Kegiatan } \\
\text { Akhir }\end{array}$ & $18-20$ & 13 & 13 \\
\hline \multicolumn{3}{|c|}{ Total Skor } & 88 & 92 \\
\hline \multicolumn{3}{|c|}{ Kriteria } & Baik & Sangat Baik \\
\hline \multicolumn{3}{|c|}{ Rata-Rata Skor Siklus 1} & \multicolumn{2}{|c|}{90} \\
\hline
\end{tabular}

Sumber: hasil pengolahan data penelitian (2018)

Berdasarkan data tabel 3 dapat dilihat aktivitas guru pada pertemuan pertama dan kedua siklus II mengalami peningkatan. Pada pertemuan pertama memperoleh skor 88 dengan kriteria baik meningkat menjadi 92 dengan kriteria sangat baik pada pertemuan kedua. 
Sehingga diperoleh rata-rata skor aktivitas guru siklus I sebesar 90.

Kemudian aktivitas siswa yang meliputi aktivitas siswa, yaitu kegiatan-kegiatan atau aktivitas-aktivitas yang dilakukan siswa selama pembelajaran. Observasi dilakukan menggunakan aspek pengamatan aktivitas yang terdiri dari 15 indikator, pengamatan dengan rentang skor penilaian1-5. Berdasarkan hasil observasi terhadap aktivitas siswa siklus II, diperoleh data hasil observasi yang disajikan dalam tabel 4 sebagai berikut.

TABEL 4

HASIL OBSERVASI AKTIVITAS SISWA SIKLUS II

\begin{tabular}{|c|c|c|c|c|}
\hline \multirow[b]{2}{*}{ No } & \multirow{2}{*}{$\begin{array}{c}\text { Aspek } \\
\text { yang } \\
\text { Diamati }\end{array}$} & \multirow[b]{2}{*}{ Indikator } & \multicolumn{2}{|c|}{ Skor } \\
\hline & & & $\begin{array}{c}\text { Pertemuan } \\
1\end{array}$ & $\begin{array}{c}\text { Pertemuan } \\
2\end{array}$ \\
\hline 1 & $\begin{array}{l}\text { Kegiatan } \\
\text { Awal }\end{array}$ & $1-4$ & 18 & 18 \\
\hline 2 & $\begin{array}{l}\text { Kegiatan } \\
\text { Inti }\end{array}$ & $5-13$ & 40 & 42 \\
\hline 3 & $\begin{array}{l}\text { Kegiatan } \\
\text { Akhir }\end{array}$ & $14-15$ & 10 & 10 \\
\hline \multicolumn{3}{|c|}{ Total Skor } & 68 & 70 \\
\hline \multicolumn{3}{|c|}{ Kriteria } & $\begin{array}{c}\text { Sangat } \\
\text { Baik }\end{array}$ & Sangat Baik \\
\hline \multicolumn{3}{|c|}{ Rata-Rata Skor Siklus 1} & \multicolumn{2}{|c|}{69} \\
\hline
\end{tabular}

Sumber: hasil pengolahan data penelitian (2018)

Berdasarkan data tabel 4, Pada pertemuan pertama diperoleh total skor sebesar 68 dengan kriteria sangat baik dan pada pertemuan kedua sebesar 70 dengan kriteria sangat baik. Sehingga rata-rata skor siklus 1 sebesar 69.

Selanjutnya data hasil belajar matematika siklus II pada siswa kelas 5 SD Negeri Sidorejo Lor o3 Salatiga setelah dilaksanakannya tes evaluasi di akhir siklus II. Nilai rata-rata kelas 84,21 dengan nilai tertinggi 100 , sedangkan nilai terendah 65 . Ketuntasan belajar siklus II diperoleh data tuntas sebanyak 35 siswa atau 83,33\% dari keseluruhan siswa, sedangkan yang belum tuntas sebanyak 7 siswa atau $16,67 \%$ dari keseluruhan siswa. Artinya hasil belajar matematika siklus II telah memenuhi indikator hasil pencapaian sebanyak $80 \%$ sehingga penerapan model pembelajaran $P B L$ berbantu media kartu soal dalam pembelajaran matematika pada kelas 5 SD Negeri Sidorejo Lor o3 Salatiga dinyatakan berhasil meningkatkan proses dan hasil belajar.

\section{Analisis Komparatif}

\section{Aktivitas Belajar}

Setelah dilakukan pengamatan terhadap proses pembelajaran matematika siklus I dan siklus II telah diperoleh data perbandingan hasil observasi aktivitas belajar yang disajikan dalam tabel 5 sebagai berikut.
TABEL 5

PERBANDINGAN ANALISIS RATA-RATA OBSERVASI SIKLUS I, SIKLUS II

\begin{tabular}{|c|c|c|c|c|c|c|}
\hline \multirow{2}{*}{$\begin{array}{l}\text { Tindak } \\
\text { an }\end{array}$} & \multicolumn{2}{|c|}{ Prasiklus } & \multicolumn{2}{|c|}{ Siklus I } & \multicolumn{2}{|c|}{ Siklus II } \\
\hline & $\begin{array}{c}\text { Juml } \\
\text { ah } \\
\text { Skor }\end{array}$ & $\%$ & $\begin{array}{c}\text { Juml } \\
\text { ah } \\
\text { Skor }\end{array}$ & $\%$ & $\begin{array}{l}\text { Juml } \\
\text { ah } \\
\text { Skor }\end{array}$ & $\%$ \\
\hline $\begin{array}{l}\text { Aktivitas } \\
\text { Guru }\end{array}$ & 71 & 71 & 81 & 81 & 92 & 92 \\
\hline $\begin{array}{l}\text { Aktivitas } \\
\text { Siswa }\end{array}$ & 51 & $\begin{array}{l}6 \\
8\end{array}$ & 62 & $\begin{array}{c}82,6 \\
7\end{array}$ & 70 & $\begin{array}{c}93,3 \\
3\end{array}$ \\
\hline
\end{tabular}

Sumber: hasil pengolahan data penelitian (2018)

Berdasarkan tabel 5 dapat diketahui bahwa terjadi peningkatan aktivitas guru dan aktivitas siswa dari siklus I dan siklus II. Pada total skor aktivitas guru siklus I memperoleh skor 81 dengan perentase $81 \%$, dan pada siklus II meningkat menjadi 92 dengan persentase $92 \%$. Rata-rata skor aktivitas siswa juga mengalami peningkatan, pada siklus I rata-rata skor aktivitas siswa 62 dengan persentase 82,67\%, kemudian meningkat pada siklus II menjadi 70 dengan persentase $93,33 \%$.

\section{Hasil Belajar}

Hasil belajar diperoleh dari tes evaluasi yang dilakukan pada setiap akhir siklus. Dari prasiklus, siklus I dan siklus II telah terjadi peningkatan nilai rata-rata kelas dan ketuntasan belajar pada pembelajaran matematika. Adapun data perbandingannya dasajikan dalam tabel 6 sebagai berikut.

\section{TABEL 6}

PERBANDINGAN KETUNTASAN DAN HASIL BELAJAR MATEMATIKA PRASIKLUS, SIKLUS I, SIKLUS II

\begin{tabular}{|c|c|c|c|c|c|c|c|}
\hline \multirow{2}{*}{$\begin{array}{l}\text { Tin } \\
\text { dak } \\
\text { an }\end{array}$} & \multirow{2}{*}{$\begin{array}{l}\mathbf{K} \\
\mathbf{K} \\
\mathbf{M}\end{array}$} & \multicolumn{2}{|c|}{ Prasiklus } & \multicolumn{2}{|c|}{ Siklus I } & \multicolumn{2}{|c|}{ Siklus II } \\
\hline & & $\begin{array}{c}\text { Jum } \\
\text { lah } \\
\text { Skor }\end{array}$ & $\%$ & $\begin{array}{l}\text { Jumla } \\
\text { h Skor }\end{array}$ & $\%$ & $\begin{array}{l}\text { Jumla } \\
\text { h Skor }\end{array}$ & $\%$ \\
\hline $\begin{array}{l}\text { Tun } \\
\text { tas }\end{array}$ & $\begin{array}{l}\geq \\
75\end{array}$ & 22 & 52 & 27 & $\begin{array}{l}64 \\
29\end{array}$ & 35 & 83,33 \\
\hline $\begin{array}{l}\text { Bel } \\
\text { um } \\
\text { Tun } \\
\text { tas }\end{array}$ & $\begin{array}{c}\leq \\
75\end{array}$ & 20 & 48 & 15 & $\begin{array}{c}35,7 \\
1\end{array}$ & 7 & 16,67 \\
\hline \multicolumn{2}{|c|}{ Jumlah } & 42 & 100 & 42 & 100 & 42 & 100 \\
\hline \multicolumn{2}{|c|}{$\begin{array}{l}\text { Nilai } \\
\text { Rata- } \\
\text { Rata }\end{array}$} & \multicolumn{2}{|c|}{73,17} & \multicolumn{2}{|c|}{73,71} & \multicolumn{2}{|c|}{84,21} \\
\hline
\end{tabular}

Berdasarkan tabel 6 tentang perbandingan ketuntasan belajar matematika, dapat diketahui bahwa terdapat peningkatan hasil belajar prasiklus, siklus I, dan siklus II. Ketuntasan belajar siswa yang diperoleh dari prasiklus siswa yang mencapai kriteria ketuntasan minimal $(K K M \geq 75)$ sejumlah 22 siswa atau $52 \%$, yang belum mencapai KKM sejumlah 20 siswa $48 \%$ dengan rata-rata hasil belajar matematika 73,17. Ketuntasan belajar pada siklus I siswa yang mencapai KKM sejumlah 
27 siswa atau 64,29\%, yang belum mencapai KKM sejumlah 15 siswa atau $35,71 \%$ dengan rata-rata hasil belajar matematika 73,71. Sedangkan katuntasan siswa pada siklus II siswa yang mencapai KKM sejumlah 35 siswa atau $83,33 \%$, yang belum mencapai KKM sejumlah 7 siswa atau $16,67 \%$ dengan rata-rata hasil belajar matematika 84,21. Dari hasil belajar matematika dan ketuntasan belajar siswa siklus II dapat diketahui bahwa indikator keberhasilan tindakan penelitian menggunakan model pembelajaran $P B L$ berbantu media kartu soal yang telah ditentukan oleh peneliti sudah tercapai (ketuntasan hasil belajar siswa $\geq 80 \%$ ).

\section{Pembahasan}

Rendahnya aktivitas belajar matematika diketahui berdasarkan hasil observasi pembelajaran matematika prasiklus kelas 5 SD Negeri Sidorejo Lor 03 Salatiga. Hasil aktivitas guru prasiklus yang memperoleh total skor 71 dengan persentase sebesar $71 \%$, kemudian aktivitas siswa memperoleh skor 51 dengan persentase sebesar $68 \%$, ketuntasan hasil belajar prasiklus siswa yang tuntas atau telah mencapai KKM ( 275$)$ sebanyak 22 siswa dengan persentase sebesar $52 \%$, sedangkan siswa yang belum tuntas sebanyak 20 siswa dengan persentase sebesar 48\%. Berdasarkan data tersebut maka perlu dilakukan tindakan perbaikan proses pembelajaran dengan meningkatkan proses dan hasil belajar matematika siswa kelas 5 SD Negeri Sidorejo Lor 03 Salatiga dapat meningkat melalui penerapan model pembelajaran $P B L$ berbantu media kartu soal.

Setelah pembelajaran matematika dengan menerapkan model pembelajaran $P B L$ berbantu media kartu soal dilaksanakan secara keseluruhan pada siklus I dan siklus II. Terbukti dari data hasil observasi guru rata-rata pada siklus I sebesar $81 \%$ dan rata-rata observasi siswa sebesar $82,67 \%$. Pada siklus II rata-rata hasil observasi guru sebesar $92 \%$ dan rata-rata observasi siswa sebesar 93,33\%. Meningkatnya aktivitas guru dan siswa diikuti dengan meningkatnya hasil belajar matematika yang terlihat dari peningkatan nilai ratarata kelas siklus I sebesar 73,71 dengan ketuntasan mencapai $64,29 \%$. Namun pencapaian tersebut belum mencapai indikator keberhasilan yang ditentukan peneliti yaitu sebesar $80 \%$, oleh karena itu diadakan refleksi sebagai perbaikan pada siklus II. Pada siklus II diperoleh nilai rata-rata kelas meningkat menjadi 84,21 dengan pencapaian ketuntasan belajar mencapai 83,33\%. Berdasarkan pencapaian ketuntasan pada siklus II, maka hasil pelaksanaan tindakan pada siklus II telah mencapai indikator ketuntasan yang ditetapkan peneliti sebesar $80 \%$ siswa tuntas.

Model $P B L$ berbantu media kartu soal membuat siswa dapat belajar dalam suasana yang menyenangkan, memiliki kemampuan untuk menemukan sesuatu yang baru, mengurangi perasaan takut dan tegang yang dirasakan oleh siswa saat mengikuti proses pembelajaran. Pembelajaran dengan menggunakan model $P B L$ berbantu media kartu soal juga menjadikan siswa dapat berinteraksi dan bekerja sama dengan baik antara siswa yang lain.

Pelaksanaan tindakan pembelajaran pada siklus I dan siklus II dengan menerapkan model pembelajaran $P B L$ berbantu media kartu soal siswa bisa merespon pertanyaan dari guru, siswa bisa mengenal masalah, siswa bisa memecahkan masalah, siswa bisa menyelidiki masalah sendiri, siswa bisa membuat soal yang sudah dijelaskan guru dan bisa berfikir secara intuisi, siswa bisa mengembangkan bakat dan kecakapan individu, siswa mempunyai kemampuan untuk menemukan hasil akhir sehingga siswa menjadi lebih aktif dan guru sebagai fasilitator dalam pembelajaran sehingga dapat meningkatkan aktivitas dan hasil belajar matematika. Berdasarkan uraian penelitian yang telah disajikan, maka penerapan model pembelajaran $P B L$ berbantu media kartu soal dalam pembelajaran matematika siswa kelas 5 SD Negeri Sidorejo Lor o3 Salatiga Tahun Pelajaran 2017/2018 terbukti bahwa penerapan model pembelajaran $P B L$ berbantu media kartu soal dapat meningkatkan proses dan hasil belajar siswa.

\section{SIMPULAN DAN SARAN}

Setelah menerapkan model pembelajaran $P B L$ dengan media kartu soal dengan langkah-langkah meliputi mengorganisasikan siswa kepada masalah, mengorganisasikan siswa untuk belajar, membantu penyelidikan mandiri dan kelompok, membuat soal dan memecahkan soal tersebut, mengembangkan dan mempresentasikan hasil karya dan menganalisis dan mengevaluasi proses pemecahan masalah pada pelajaran matematika dapat dianalisis kesimpulan bahwa penerapan model pembelajaran $P B L$ dengan media kartu soal dapat meningkatkan proses dan hasil belajar matematika siswa kelas 5 SD Negeri Sidorejo Lor 03 Salatiga Tahun Pelajaran 2017/2018. Diketahui hasil observasi aktivitas guru siklus I rata-rata aktivitas guru $81 \%$, pada siklus II rata-rata aktivitas guru meningkat menjadi 92\%. Peningkatan juga terlihat pada hasil observasi aktivitas siswa. Hasil observasi siswa siklus I rata-rata aktivitas siswa $82,67 \%$, pada siklus II rata-rata aktivitas siswa meningkat menjadi 93,33\%.

Seiring dengan hasil aktivitas guru dan aktivitas siswa yang meningkat maka berpengaruh terhadap hasil belajar matematika siswa yang juga meningkat. Hal ini dapat dibuktikan dari perolehan nilai siswa kondisi awal hingga pada pelaksanaan tiap siklusnya yang mengalami peningkatan. Pada kondisi awal mula-mula nilai ratarata hasil tes matematika siswa kelas 5 SD Negeri Sidorejo Lor 03 Salatiga adalah 73,17 dengan persentase ketuntasan siswa sebesar 52\%. Kemudian setelah pelaksanaan tindakan siklus I dengan menerapkan model pembelajaran $P B L$ dengan media kartu soal hasil belajar matematika mengalami peningkatan dari perolehan kondisi awal sebelumnya, nilai rata-rata yang diperoleh siswa setelah pelaksanaan tindakan siklus I 
menjadi 84,21 dengan persentase ketuntasan 64,29\%, setelah pelaksanaan tindakan pembelajaran pada siklus II nilai rata-rata hasil evaluasi matematika meningkat menjadi 88,7 dengan persentase ketuntasan 83,33\%. Sehingga penerapan model $P B L$ dengan media kartu soal terbukti dapat meningkatkan proses dan hasil belajar matematika siswa kelas 5 SD Negeri Sidorejo Lor 03 Salatiga Tahun Pelajaran 2017/2018.

\section{Saran}

1. Bagi Guru. Guru hendaknya lebih kreatif dan inovatif dalam memberikan motivasi kepada siswa agar lebih aktif mengikuti pembelajaran dan memberikan sikap positif terhadap hasil aktivitas belajar siswa.

2. Bagi Siswa. Siswa hendaknya lebih memahami konsep materi pelajaran dan aktif dalam mengikuti proses pembelajaran serta siswa belajar secara berkelompok dan saling bertukar pengetahuan, guna memperoleh pengetahuan dan pemahaman yang dapat meningkatkan hasil belajar.

3. Bagi Sekolah. Sekolah sebagai lembaga pendidikan harus memantau proses pembelajaran agar lebih efektif terhadap hasil belajar. Penerapan model pembelajaran yang inovatif dalam kegiatan belajar mengajar dapat dijadikan referensi untuk memperbaiki mutu dan kualitas pembelajaran di sekolah sehingga meningkatkan kepercayaan diri masyarakat kepada sekolah.

\section{UCAPAN TERIMA KASIH}

Dengan ini penulis mengucapkan terimakasih kepada Bapak Drs. Nyoto Harjono, M.Pd. dan Bapak Gamaliel Septian Airlanda, M.Pd. yang telah membimbing dan memberi arahan sehingga penulis dapat menyelesaikan tugas akhir dengan baik.

\section{DAFTAR RUJUKAN}

[1] Agus, Suprijono. 2013. Cooperative Learning Teori dan Aplikasi PAIKEM. Yogyakarta: Pustaka Pelajar.

[2] Andriastutik, Siti Novi. 2013. Penerapan Model Problem Based Learning (PBL) Pada Pembelajaran Matematika Dalam Upaya meningkatkan Hasil Belajar Matematika Siswa Kelas 5 Semester II Sekolah Dasar Negeri 6 Sindurejo Tahun Ajaran 2012/2013. Skripsi. Salatiga: UKSW. Pada tanggal 3 Oktober 2017.

[3] Andriaswari, Ni Made Putri, dkk. 2016. "Penerapan Model Pembelajaran Based Learning (PBL) Berbantuan Media Konkret Dapat Meningkatkan Penguasaan Kompetensi Pengetahuan Matematika Siswa Kelas 5B SD Negeri 10 Pemecutan". E-Journal PGSD Universitas Pendidikan Ganesha. 4(1). Diakses melalui: https://ejournal.undiksha.ac.id/index.php/JJPGSD/ article/view/7164 pada tanggal 3 Oktober 2017.

[4] Berliana, dkk. 2012. Belajar Pembelajaran dalam Pelatihan Olahraga. Bandung: FPOK UPI Bandung.
[5] Daryanto. 2014. Pembelajaran Tematik, Terpadu, Terintegrasi (Kurikulum 2013). Yogyakarta: Gava Media.

[6] Dimyati, Mudjiono. 2013. Belajar dan Pembelajaran. Jakarta: Rineka Cipta.

[7] Haryanto, Ari. 2011. Penerapan Problem Based Learning Berbantuan Permainan Ular Tangga Untuk Meningkatkan Hasil Belajar Matematika Kelas IV SD Negeri o3 Jambangan Kecamatan Geyer Kabupaten Grobogan Semester 1 Tahun Ajaran 2015/2016. Skripsi. Salatiga: UKSW. Pada tanggal 9 Oktober 2017.

[8] Heruman.2012. Model Pembelajaran Matematika di Sekolah Dasar. Bandung: PT Remaja Rosdakarya.

[9] Hosnan. 2014. Pendekatan saintifik dan kontektual dalam Pembelajaran Abad 21. Bogor: halia Indonesia.

[10] Karso, dkk. 2011. Pendidikan Matematika I. Jakarta: Universitas Terbuka.

[11] Khamdani, Rifki. 2012. Penggunaan Model Pembelajaran Berbasis Masalah (PBL) Untuk Meningkatkan Hasil Belajar Matematika Siswa Kelas 5 SD Negeri Kemligi Kecamatan Wonotunggal Kabupaten Batang Tahun Pelajaran 2013/2014. Skripsi: UKSW. Pada tanggal 3 Oktober 2017.

[12] Khoiri, Wafik, dkk. 2013. Problem Based Learning Berbantuan Multimedia Dalam Pembelajaran Matematika Untuk Meningkatkan Kemampuan Berpikir Kreatif. Unnes Journal Of Mathematics Education. 2 (1). Semarang. Pada tanggal 3 Oktober 2017.

[13] Ngalimun. 2014. Strategi dan Model Pembelajaran. Jakarta: Aswaja.

[14] Permendiknas. 2006. Peraturan Menteri Pendidikan Nasional Republik Indonesia Nomor 22 Tahun 2006 Tentang Standar Isi Untuk Satuan Pendidikan Dasar Dan Menengah.

[15] Rusmono. 2012. Strategi Pembelajaran dengan Problem Based Learning itu Perlu Untuk Meningkatkan Profesionalitas Guru. Bogor. Ghalia Indonesia.

[16] Sitiava, Rizema Putra. 2013. Desain Belajar Mengajar Kreatitif Berbasis Sains. Jogjakarta: Diva Press.

[17] Sriyanto. 2011. Strategi Sukses Menguasai Matematika. Yogyakarta: Indonesia Cerdas.

[18] Sudarmono. 2008. Upaya Meningkatkan Kemampuan Siswa Dalam Mengerjakan Soal Cerita ada Mata Pelajaran Matematika Melalui Metode Bermain Kartu Soal Bagi Siswa Kelas 5I SD Negri Jeruk Legi Wetan 01 Kabupaten Cilacap Tahun Pelajaran 2007/2008. (Laporan PTK). Cilacap: Dinas Pendidikan Kabupaten Cilacap. Pada tanggal 3 Oktober 2017.

[19] Sudjana, Nana. 2010. Penilaian Hasil Proses Belajar Mengajar. Bandung: PT Remaja Rosdakarya

[20] Susanto, Ahmad. 2013. Teori Belajar dan Pembelajaran di Sekolah Dasar.Jakarta: Kencana Prenada Media Group.

[21] Trianto. 2013. Mendesain Model Pembelajaran Inovatif Progresif: Konsep, Landasan, dan Implementasinya pada Kurikulum Tingkat Satuan Pendidikan (KTSP). Jakarta: Kencana Prenada Media Group.

[22] Vitasari, Rizka. 2012. Peningkatan Keaktifan dan Hasil Belajar Matematika Melalui Model Problem Based Learning Siswa Kelas 5 SD Negeri 5 Kutosari. Surakarta: UNS. Pada tanggal 9 Oktober 2017.

[23] Wahyudi. 2011. Penerapan Problem Based Learning Untuk Meningkatkan Kemampuan Berpikir Logis Dan Sikap Positif Siswa. Jurnal Penelitian Pengembangan pendidikan. Salatiga: Universitas Kristen Satya Wacana. Pada tanggal 3 Oktober 2017. 
[24] Warsono, dkk. 2013. Pembelajaran Aktif. Bandung: Remaja Rosdakarya. Diakses melalui: http://www.unpad.ac.id/wpcontent/uploads/2013/11/UU20-2003-Sisdiknas.pdf Pada tanggal 3 Oktober 2017.

[25] Wisudawati, Asih Widi dan Sulistyowati, Eka. 2014. Metodologi Pembelajaran IPA. Jakarta : PT. Bumi Aksara.

\section{PROFIL PENULIS UTAMA}

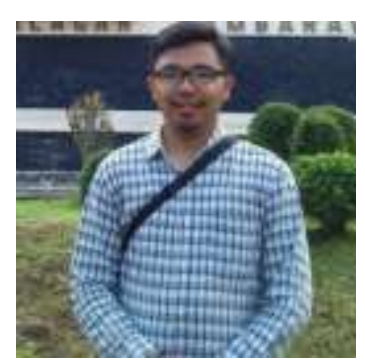

Penulis bernama lengkap "Damasus Fajar Nugroho". Lahir di Desa Sumogawe Kecamatan Getasan Kabupaten Semarang Provinsi Jawa Tengah pada tanggal 11 Desember 1995 dari pasangan Herdianto dan Suparmi. Penulis adalah anak pertama dari 2 bersaudara. Pendidikan sekolah dasar dimulai dari SD Kanisius Harjosari Kecamatan Bawen pada tahun 2002 - 2008. Setelah itu melanjutkan pendidikan sekolah menengah ke SMP Pangudi Luhur Ambarawa pada tahun 2008 - 2011 dan terakhir di SMAN 1 Getasan pada tahun 2011 - 2014. Kemudian penulis melanjutkan studi ke perguruan tinggi di Program Studi Pendidikan Guru Sekolah Dasar FKIP UKSW pada tahun 2014. Kritik, saran, maupun hal-hal yang berkaitan dengan kelanjutan atau pengembangan dari hasil penelitian ini bisa dikirim ke email penulis di : fajar2nugraha@gmail.com 